\title{
Feasibility of a Permeable Pavement Option in SWMM for Long-term Continuous Modeling
}

Craig W. Kipkie and William James

With increasing concern for the natural environment, current practices in stormwater management planning have moved away from traditional applications such as detention as a means of quantity control, towards techniques that combine both quantity and quality control. These techniques lower stormwater runoff volumes, recharge groundwater and mitigate the transportation of contaminants. One such type of management practice is installation of permeable pavement.

The purpose of this study was to examine the feasibility of code for the Storm Water Management Model (SWMM) to allow planners and designers to simulate the responses of permeable pavements in long-term modeling applications. The infiltration capacity of the porous pavement was determined from past studies, and takes into account degradation over time and regeneration by mechanical means.

\subsection{Introduction}

Humans tend to congregate in large cities with high population densities. To support these populations, cities require extensive infrastructures. Forests, fields, marshes, and creeks have been replaced with buildings, roads, parking lots

Kipkie, C. and W. James. 2000. "Feasibility of a Permeable Pavement Option in SWMM for Long-term Continuous Modeling." Journal of Water Management Modeling R206-18. doi:

10.14796/JWMM.R206-18.

(C) CHI 2000 www.chijournal.org ISSN: 2292-6062 (Formerly in Applied Modeling of Urban Water Systems. ISBN: 0-9683681-3-1) 
and pipes. Such urbanization changes the natural hydrology of the watershed. With less water infiltrating into the ground, streams and rivers have higher volumes of water entering their systems during storms (Schueler, 1987; Ferguson. 1994). Sealing of the land surfaces with pavements and roofs creates a new hydrological land type. Increases in the impervious areas has had the inevitable result of increasing stormwater runoff and volumes (Weatherbe, 1995), decreasing low-flow volumes and groundwater base-flow, degrading water quality, and increasing streambank erosion (Maryland Department of Natural Resources, 1984). Urban areas also act as large heat receptors, which can cause micro-climatic changes (Schueler, 1987; Xie and James, 1993), and affect the temperature of receiving waters (warmer in the summer months - colder in the winter months), resulting in the destruction of sensitive aquatic habitats.

Surfaces used by motorized vehicles, such as highways and parking lots, can contribute large quantities and wide ranges of pollutants to stormwater. Many pollutants are deposited on paved surfaces from the vehicles' exhaust. Types of pollutants associated with exhaust are carbon monoxide, hydrocarbons, nitrogen and sulphur oxides and the heavy metal lead. Metal pollutants can also be released from the corrosion of vehicle parts and from the degradation of tires onto the paved surface. Erosion of tires can release zinc into the environment (Mikkelsen et al., 1993). Contamination of stormwater from engine leaks or accidental spills can be sources of oil and hydrocarbon pollution. Since most of the pollutants found on these types of paved surfaces are related to vehicular traffic, there will be increased concentration levels with increases in average daily traffic.

The types of pollutants found in stormwater from industrial sites are highly dependent upon the particular type of industry and management practices employed at the site. Heavily industrialized areas may have high levels of pollutants associated with atmospheric deposition and from the use of different industrial materials. Runoff from these types of surfaces can result in highly polluted stormwater (James and Shivalingaiah, 1985)

Destruction of the natural environment, as a result of human impacts, is an issue that has been recently brought to the forefront. One of the more important environmental concerns facing human kind is the contamination of the Earth's water supply. Eliminating pollution from drinking water is an aspect of water management that is now affecting the practices of urban planners and designers.

Current practices in stormwater management planning are moving away from applications such as detention ponds as a means of flood control towards techniques that combine both stormwater quantity and quality control. Such methods are considered to be environmentally responsible management techniques (Kresin et al., 1996). These techniques focus on reducing runoff volumes, recharging groundwater supplies and managing the transportation of contaminants. Various options are available to designers and planners, such as infiltration 
basins, infiltration trenches, and seepage trenches. More recently, an option that is getting greater attention from the stormwater management community in North America is installation of permeable pavement.

Differences exist in literature in the use of the synonymous terms porous pavement and permeable pavement. In this study, permeable pavement is taken to mean the entire structure of an installation, including both the surface porous pavement layer and the underlying structure, which incorporates the base course, subgrade, and possibly a filter membrane.

Since 1960 , computer programs have become increasingly available to designers and planners for simulating the various scenarios that occur in urban water systems. Models give the user a greater understanding of the hydrologic, hydraulic and water quality responses that an urban area may have and allow the user to evaluate hypothetical scenarios without the high cost of physical tests. Presently, the most widely used stormwater model is the United States Environmental Protection Agency's (USEPA's) Storm Water Management Model (SWMM) (James, 1994; Nix, 1994). According to Huber and Dickinson (1988), SWMM simulates "all aspects of the urban hydrologic and quality cycles", and evaluates the effectiveness of various best management practices (BMPs). However, SWMM does not give designers and planners the opportunity to examine the effectiveness of permeable pavement as a method of reducing stormwater quantities and improving overall water quality.

The main objective of this study was to examine the feasibility of inserting new FORTRAN computer code into SWMM to allow planners and designers to simulate the hydrologic response of permeable pavements in long-term modeling applications. It should be seen as an attempt to formulate code that would improve the modeling capabilities of SWMM by adding an eco-sensitive urban stormwater management technique.

\subsection{Background}

No new field or laboratory studies were completed for this study. The infiltration capacity of permeable pavement is established from previous research.

Infiltration capacity of the porous pavement, the storage capacity of the pavement reservoir, and its drainage (the infiltration capacity of the underlying native soil) control the hydrologic response of a permeable pavement installation. Installations attempt to reproduce the pre-development hydrologic regime that was present before urbanization (Schueler, 1987). The main purpose of this type of stormwater management practice is to reduce the volume of runoff that will reach receiving waters. There have been various investigations into the performance of permeable pavement installations. 
Muth (1988) conducted laboratory investigations on $2 \mathrm{~m}$ by $2 \mathrm{~m}$ UNI EcoStone plots. Experiments involved the use of a rainfall simulator to provide variable rainfall intensities to different plot slopes. Flat slopes provided no surface runoff from rainfall intensities up to $72 \mathrm{~mm} / \mathrm{h}$ and slopes of $2.5 \%$ did not have surface runoff for rainfall up to $36 \mathrm{~mm} / \mathrm{h}$. Muth observed an infiltration capacity of $1.8 \mathrm{~mm} / \mathrm{h}$ after 20 minutes.

Pratt et al. (1989) constructed a $4.6 \mathrm{~m}$ by $40 \mathrm{~m}$ experimental parking lot at the Clifton Campus of Trent Polytechnic. The study examined the hydrologic response of a MICBEC (modular interlocking concrete block- internal drainage cell type) installation with four different types of reservoir material. Results of the experiment showed that $40 \mathrm{~mm}$ blast furnace slag produces the least runoff volume. This finding was attributed to the honeycomb structure of the slag reservoir. Granite aggregate, ranging between $5-40 \mathrm{~mm}$ in size, produced the highest volume of runoff. It was concluded that this occurred because of the granite's lower surface area for wetting compared to the $10 \mathrm{~mm}$ gravel and to its limited adsorption potential relative to the $5-40 \mathrm{~mm}$ carboniferous limestone. Attenuation of the peak was between 5 to $10 \mathrm{~min}$ when compared to impermeable surfaces (time of concentration between $2-3 \mathrm{~min}$ ). Pratt et al. (1989) suggested that the stormwater discharge characteristics could be further enhanced on larger constructions, since part of the flow attenuation is derived from the time to travel to, and within, the sub base drains. Difference in the material type, particle size and distribution, and properties have been shown to be very important in the design of the permeable pavement reservoir structure. From the results Pratt et al. (1995) developed a computing model for the stormwater outflow volume from permeable pavement drains with different reservoir structures.

Saturated hydraulic conductivities of different UNI Eco-Stone drainage cell material types were investigated by Phalen (1992) and the results compared well with Muth's (1988) experiments. External drainage cells (EDCs) consisting of sand alone had saturated hydraulic conductivities ranging from 33.0 to 68.6 $\mathrm{mm} / \mathrm{hr}^{-1}$ compared to values that Muth observed for a sand-covered test plot (71 $\left.\mathrm{mm} / \mathrm{hr}^{-1}\right)$. Rollings and Rollings (1993) concluded that the fine-grained sand would control the infiltration capacity of the EDC. Saturated hydraulic conductivities ranging from 475.0 to $4368.8 \mathrm{~mm} / \mathrm{hr}^{-1}$ were observed in tests with increasingly coarse drainage material (Phalen, 1992).

Nawang and Saad (1993) conducted experiments on a PAP (porous asphalt pavement) installation. Results indicated a $62 \%$ reduction in the peak flow when compared to a conventional asphalt paving installation. The peak flow occurred after $61 \mathrm{~min}$ of the rainfall event compared to $21 \mathrm{~min}$ for the conventional asphalt installation.

Borgwardt (1994) conducted field experiments, in a similar manner to Kresin (1996), at two UNI Eco-Stone installations ( $2 y$ and $5 y$ in age). Infiltration capacities of the sites were determined and the effect of age of the installation on 
these values was also investigated. Results of the experiments showed that due to higher fine material content in EDC material the infiltration capacity for the 2year old site was lower $\left(1.2 \mathrm{~mm} / \mathrm{h}^{-1}\right)$ than the 5 -year old site $\left(2.4 \mathrm{~mm} / \mathrm{h}^{-1}\right)$. Borgwardt observed constant infiltration capacities occurring at rainfall durations between 10 and $30 \mathrm{~min}$.

Shackel (1995) examined infiltration capacities of a UNI Eco-Stone installation with different combinations of bedding, jointing and drainage cell material. The material ranged from $2 \mathrm{~mm}$ sand to $10 \mathrm{~mm}$ gravel. The laboratory experiments used rainfall tests with intensities higher than those normally experienced in Europe. Results showed that the highest infiltration capacity $\left(216 \mathrm{~mm} / \mathrm{hr}^{-1}\right)$, with proper joint filling, occurred with the use of uniform and clean 2-5 mm gravel fill. Shackel's experiments also substantiated Rollings and Rollings (1993) conclusion that the addition of fines or sands to the drainage material significantly reduces the infiltration capacity of the pavement.

Kresin (1996) measured infiltration capacity at a number of UNI Eco-Stone installations of various ages. Two constant rate rainfalls were applied to $0.7 \mathrm{~m}^{2}$ test plots by a portable rainfall simulator in order to account for initial losses to soil wetting. A total of 60 tests were completed at four test sites. Site 1, with a service period of $3 \mathrm{y}$ was at the Parking Lot P10 at the University of Guelph and adjacent land use consisted of asphalt parking areas as well as a small grassed area. Site 2 was at the Belfountain Conservation Area parking lot in Belfountain, Ontario. This site had only been in service for one year and was not utilised in the winter and, therefore, was not subjected to a winter maintenance program. Site3 was a service laneway, with minimal traffic and winter maintenance, at an apartment complex in Dundas, Ontario. The site had been in operation for a oneyear period. The fourth site was back laneway/ parking area located in Toronto, Ontario. Site 4 had a service period of $3 y$ and was bordered by residential garages and subjected to minimal winter maintenance. The study determined the overall average effective infiltration capacity $\left(f \mathrm{E}_{\mathrm{o}}\right)$ for each site, the particle distribution of the EDC material, the regenerated average effective infiltration capacity, and the particle distribution of the crust (top $5 \mathrm{~mm}$ ) removed during the regeneration process. Table 18.1 summarizes the results of this study.

Table 18.1 Summary of results obtained by Kresin (1996).

\begin{tabular}{|c|c|c|c|c|c|c|}
\hline $\begin{array}{l}\text { Site } \\
\text { Number }\end{array}$ & $\begin{array}{c}\mathrm{fe}_{\odot} \\
(\mathrm{mm} / \mathrm{h})\end{array}$ & $\begin{array}{c}\text { EDC } \\
\% \text { Passing } \\
\# 200\end{array}$ & $\begin{array}{c}\text { EDC \% } \\
\text { OM }\end{array}$ & $\begin{array}{l}\text { Regenerated } \\
\mathrm{fE}_{\mathrm{o}}(\mathrm{mm} / \mathrm{h})\end{array}$ & $\begin{array}{c}\text { Crust } \\
\% \text { Passing } \\
\# 200\end{array}$ & $\begin{array}{l}\text { Crust } \\
\% \mathrm{OM}\end{array}$ \\
\hline $1 \mathrm{~A}$ & 3.6 & 8.7 & 0.18 & $5.0^{*}$ & & \\
\hline $1 \mathrm{~B}$ & 5.8 & 6.6 & 0.19 & 7.7 & 15.9 & 0.58 \\
\hline 2 & 14.9 & 1.9 & 0.39 & 40.0 & 5.5 & 0.62 \\
\hline 3 & 34.3 & 3.3 & 0.22 & & & \\
\hline 4 & 7.9 & 5.5 & 0.38 & & & \\
\hline
\end{tabular}

* Site $1 \mathrm{~A} f E_{o}$ regenerated using street sweeper/vacuum. 


\subsection{Changes to SWMM Code}

SWMM 4 encompasses over 200 Fortran files (.FOR extension) and include files (.INC). Addition and changes to the source code is a daunting task, since the code itself encompasses approximately 76,000 lines. There have been numerous authors and limited documentation, of the source code, since its inception in 1969.

Kipkie (1998) incorporated various changes and additions into the SWMM RUNOFF source code for the inclusion of a permeable pavement surface type. Subroutines changed were CATCH.FOR, RHYDRO1.FOR, WSHED.FOR and the INCLUDE file DETAIL.INC. An additional subroutine, PERMPAV.FOR was developed as well as the INCLUDE file PERMEA.INC. The following briefly summarizes the changes and additions - a more complete description can be found in the thesis by Kipkie (1998).

\section{DETAIL .INC}

Currently, the RUNOFF block in SWMM 4 contains four different surface types that can be modeled within each subcatchment. The four types include: impervious, with detention; pervious, with detention; impervious, with zero detention and; impervious, with snow simulation. In order to accommodate the new surface type, within the RUNOFF block, the upper limit of certain twodimensional arrays had to be increased.

\section{RHYDRO1.FOR}

During the executing of the SWMM program certain circumstances allow for specific computations to be missed, resulting in improved program efficiency. Therefore, the switch PERMEA has been incorporated into the code. The information for this parameter is inputted at the end of the B1 card line. Switching on (enter 1) activates the permeable pavement calculations.

\section{CATCH.FOR}

In the RUNOFF module, the subcatchment surface data is entered in the H1 data lines. In order to incorporate the permeable pavement, for each subcatchment, an H6 line had to added to the data input line. Each H6 line corresponds to a particular $\mathrm{H} 1$ input line. Table 18.2 describes the data required to simulate the hydrologic response of permeable pavement.

The program then calculates the area of the permeable pavement component of the subcatchment by the following equation:

$$
A_{p p}=A_{s} \cdot \frac{(100-i m p) \cdot(\text { perv })}{100}
$$


where:

$$
\begin{aligned}
\mathrm{A}_{\mathrm{pp}} & =\text { permeable pavement area, } \mathrm{m}^{2} \\
\mathrm{~A}_{\mathrm{s}} & =\text { subcatchment area, } \mathrm{m}^{2} \\
\mathrm{imp} & =\text { percent imperviousness } \\
\text { perv } & =\text { percent of pervious area that is permeable pavement }
\end{aligned}
$$

The program then recalculates the subcatchment's pervious area by subtracting from the total pervious area from the area that is permeable pavement

At the end of the CATCH.FOR subroutine, the program outputs summary information such as the number of watersheds, the total area of the catchments, the area that is impervious, and the area that is pervious. If the permeable pavement option is switched on, the total permeable pavement area for the subcatchment is also printed. If the permeable pavement area is equal to zero (the

\begin{tabular}{|c|c|c|}
\hline Variable & Description & Default \\
\hline & $\begin{array}{l}\text { REPEAT GROUP H6 FOR EACH SUBCATCHMENT } \\
\text { THAT CONTAIN PERMEABLE PAVEMENT }\end{array}$ & \\
\hline H6 & Group Identifier & None \\
\hline PERAREA & $\begin{array}{l}\text { Percentage of the pervious area for the specific } \\
\text { subcatchment that is permeable pavement }(\%)\end{array}$ & None \\
\hline PWSTORE & Depression Storage for permeable pavement, in (mm) & None \\
\hline PRESIS & Permeable pavement area Manning's roughness & None \\
\hline PSUCT & $\begin{array}{l}\text { Average capillary suction, in. }(\mathrm{mm}) \text { of water for the upper } \\
\text { layer of the permeable pavement installation }\end{array}$ & None \\
\hline PHYDCON & $\begin{array}{l}\text { Saturated hydraulic conductivity of soil, in. } / \mathrm{hr}(\mathrm{mm} / \mathrm{hr}) \text { for } \\
\text { the upper most layer of the permeable pavement } \\
\text { installation }\end{array}$ & None \\
\hline PSMDMAX & $\begin{array}{l}\text { Initial moisture deficit for soil, volume air/volume voids } \\
\text { (fraction) upper most layer of the permeable pavement } \\
\text { installation }\end{array}$ & None \\
\hline DEGRAD & Degradation coefficient, time ${ }^{-1}$ & None \\
\hline PREGEN & $\begin{array}{l}\text { Average length of time between mechanical regeneration of } \\
\text { permeable pavement infiltration properties (days) }\end{array}$ & None \\
\hline
\end{tabular}
option is switched off) the program prints the standard statistics that were originally in the SWMM 4 source code.

Table 18.2 RUNOFF block input data - H6 line.

\section{WSHED.FOR}

WSHED.FOR subroutine is called with the HYDRO.FOR subroutine. This part of the RUNOFF module is the source code for computing the instantaneous water depths and flow rates for the subcatchment areas. Changes to specific DO loops were made to include permeable pavement water depth and low rate calculations. If the hydrologic response of permeable pavement is being modeled, subroutine PERMPAVE.FOR is called at this point to calculate possible infiltration losses that occur during a rain event. 


\section{PERMEA.INC}

The introduction of the new surface type created the need for the addition of another INCLUDE or .INC file. This file enables the passing of the variables associated with the permeable pavement option.

\section{PERMPAV.FOR}

PERMPAV.FOR subroutine was developed for modeling the hydrological response of permeable pavement. The subroutine is based on the Green-Ampt method for calculating the infiltration that is associated with this surface type. The coding is similar to the GAMP.FOR that is used for the infiltration calculations for the pervious surface type. Within this subroutine is the source code that is the main focus of this thesis study. As previously mentioned, one of the major difficulties associated with the use of permeable pavement is the loss of porosity due to clogging of the voids within the structure of the porous material layer. Clogging of the porous layer and the reduction of the infiltration properties has been shown to occur within one to five years after construction (Urbonas and Stahre, 1994; Kresin, 1996). Some of the factors determining the time-to-sealing are traffic density, adjacent landuse, and types of material used for the porous layer.

Some researchers (Kresin, 1996; Pratt et al., 1989) have suggested that the performance of the permeable pavement structure is controlled by the infiltration capacity of the porous pavement, the storage capacity of the reservoir, and the hydraulic conductivity of the underlying native soil. Ideally, in order to incorporate permeable pavement into SWMM RUNOFF the model would simulate the rainfall event response for an installation as three hydrologically connected systems; the porous pavement, the reservoir and the underlying soil. The modeler would input the hydraulic parameter for the porous pavement layer such as saturated hydraulic conductivity, the soil suction and the initial soil moisture deficit. The reservoir would be treated as a volume that would be filled during a rainfall event. Therefore, the parameters needed for the reservoir would be depth and porosity. The saturated hydraulic conductivity of the underlying soil as well as the soil suction and initial moisture deficit would also have to be inputted.

In keeping with the current structure of SWMM 4 it was decided to use the Green-Ampt subroutine to model the infiltration based on the upper most layer of the soil. Within SWMM, this layer is calculated using the following equation:

$$
\mathrm{L}=4 \sqrt{\mathrm{K}_{\mathrm{s}}}
$$

where:

$$
\begin{aligned}
\mathrm{L} & =\text { depth of the upper most layer, } \mathrm{mm} \text { (in.) } \\
\mathrm{K}_{\mathrm{s}} & =\text { saturated hydraulic conductivity, } \mathrm{mm} / \mathrm{h}^{-1}\left(\mathrm{in} / \mathrm{h}^{-1}\right)
\end{aligned}
$$


Sample calculations using the above equation were completed and are summarized in the following table:

Table 18.3 Upper most layer calculations.

\begin{tabular}{cc} 
Saturated hydraulic $\mathrm{K}_{\mathrm{s}}(\mathrm{mm} / \mathrm{h})$ & Depth of the upper most layer $(\mathrm{m})$ \\
\hline 12.7 & 0.07 \\
19.1 & 0.09 \\
25.4 & 0.10 \\
38.1 & 0.12 \\
50.8 & 0.14 \\
76.2 & 0.18 \\
\hline
\end{tabular}

For even a very high saturated conductivity $\left(76.2 \mathrm{~mm} / \mathrm{h}^{-1}\right)$, it can be seen that the depth of the upper most layer that governs infiltration is relatively small. Pratt et al. (1989) suggest that the upper permeable pavement layer averages 0.07 $\mathrm{m}$ to $0.1 \mathrm{~m}$ and the reservoir structure ranges from $0.3 \mathrm{~m}$ to $0.5 \mathrm{~m}$. Therefore, if the SWMM methodology for modeling infiltration of pervious areas is to be adopted it does not seem necessary to use the representation of two hydrologically connected systems for the permeable pavement structure.

In an attempt to simulate the degradation of the infiltration properties of the porous layer, saturated hydraulic conductivity of the soil was altered over time. It was decided that the degradation should be related to an exponential decay function. The function is given by the following equation:

where:

$$
\mathrm{K}_{\mathrm{s} \mathrm{new}}=\left(\mathrm{K}_{\text {sinitial }}\right) e^{-\mathrm{Kt}}
$$

$$
\begin{aligned}
\mathrm{K}_{\mathrm{s} \text { initial }}= & \text { initial saturated hydraulic conductivity, } \mathrm{mm} / \mathrm{h}^{-1} \\
& \left(\mathrm{in} / \mathrm{h}^{-1}\right) \\
\mathrm{K}_{\mathrm{snew}}= & \text { new calculated saturated hydraulic conductivity, } \\
& \mathrm{mm} / \mathrm{h}^{-1}\left(\mathrm{in} / \mathrm{h}^{-1}\right) \\
\mathrm{t}= & \text { time from construction of the permeable pavement or } \\
& \text { the time since regeneration has occurred, } \mathrm{d} \\
\mathrm{K}= & \text { decay coefficient, time } \mathrm{e}^{-1}
\end{aligned}
$$

The initial saturated hydraulic conductivity and the decay coefficient are inputted by the modeler and are good candidate parameters for calibration.

Figure 18.1 shows that with an exponential decay function, the saturated hydraulic conductivity of the porous layer sharply decreases during early parts of the simulation. The function then approaches zero which means that after considerable amount of time the surface is, for all intents and purposes, impermeable. 


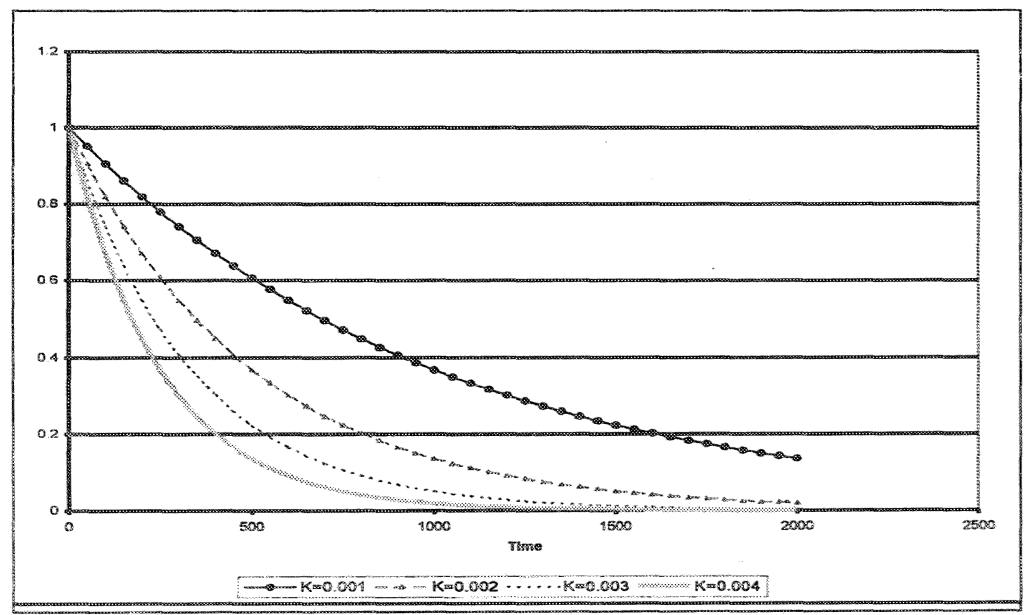

Figure 18.1 Exponential decay tunction with different decay coefficients.

\section{Quality assurance}

Upon successful compilation of the additions and changes to the source code that were completed in order to simulate the long-term hydrologic response of permeable pavement, several tests were completed. The objectives of these tests were the following:

- check to see if the model was performing properly with the new subroutine and code changes

- model long-term simulations of the permeable installations and examine the credibility of the results

To ensure that the new model was producing reasonable results the following was accomplished:

- addition of write statements to the source code at various points in the subroutines

- completion of hand calculations to confirm various values outputted in step 1

- the modeling of various scenarios for a hypothetical catchment and modifying various parameters to compare computed hydrograph results

\subsection{Results and Discussion}

A RUNOFF test file was produced for the simulations conducted for this study. This hypothetical catchment consisted of 10 subcatchments, each having similar properties. Each subcatchment measured 23.5 ha $(58 \mathrm{ac})$ and had a slope of $2 \%$. 
The rain data that was used for the simulations was from Station 61533009 in Hamilton, Ontario. The data consisted of continuous hourly rainfall from May 1 , 1971 to August 31, 1989.

\subsubsection{Test 1- Comparison of Non-Degradable versus Degradable Permeable Pavement}

The first test examined how the new version of SWMM RUNOFF modeled the degradation of the infiltration properties over time. Each subcatchment had similar properties. There was no impervious surface and half of the subcatchment was permeable pavement, while the other half was the standard pervious surface type. The parameters for the permeable pavement part of the subcatchment are summarized in Table 18.4.

Table 18.4 Test 1 permeable pavement parameters.

\begin{tabular}{clcc}
\hline Variable & \multicolumn{1}{c}{ Description } & Value \\
\hline PERAREA & $\begin{array}{l}\text { Percentage of the pervious area for the specific } \\
\text { subcatchment that is permeable pavement (\%) }\end{array}$ & 50.0 \\
PWSTORE & $\begin{array}{l}\text { Depression storage for permeable pavement, in } \\
\text { (mm) }\end{array}$ & $0.17(4.3)$ \\
PRESIS & $\begin{array}{l}\text { Permeable pavement area Manning's roughness } \\
\text { Average capillary suction, in (mm) of water for }\end{array}$ & 0.024 \\
PSUCT & $\begin{array}{l}\text { lhe upper layer of the permeable pavement } \\
\text { installation }\end{array}$ & $4.00(102)$ \\
PHYDCON & $\begin{array}{l}\text { Saturated hydraulic conductivity of soil, in/h } \\
\text { (mm/h) for the upper layer of the permeable } \\
\text { pavement installation } \\
\text { PSMDMAX }\end{array}$ & $\begin{array}{l}\text { Initial moisture deficit for soil, volume } \\
\text { air/volume voids (fraction)) for the upper layer } \\
\text { of the permeable pavement installation } \\
\text { Degradation coefficient, d }\end{array}$ & $0.5(12.7)$ \\
DEGRAD & $\begin{array}{l}\text { Average length of time between mechanical } \\
\text { regeneration of permeable pavement infiltration } \\
\text { properties (d) }\end{array}$ & 0.34 \\
PREGEN & 0.5 to 6000 \\
\hline
\end{tabular}

In Test 1 the only parameter that changes is PREGEN. When PREGEN $=0.5 \mathrm{~d}$ the saturated hydraulic conductivity is regenerated every half day. Therefore, there is virtually no change in this property. When PREGEN $=6000 \mathrm{~d}$ or $16.4 \mathrm{y}$ the saturated hydraulic conductivity is degraded over time.

Three separate events during the 18 y period were examined. These events were selected so that there was no rainfall event in the previous $5 \mathrm{~d}$. This eliminated the possibility of antecedent moisture conditions affecting the results. Figure 18.2 shows the hydrograph (outlet 9501) for a storm event that occurred on May 15, 1971. This event was very close to the beginning of the simulation 
and, therefore, the permeable pavement installation could be considered newly constructed. The results of the hydrograph show that the flows from both test runs are identical. These results are reasonable since the saturated hydraulic conductivities for subcatchments for both runs should be nearly the same.

The next event that was selected for comparison occurred approximately five years later from May 24-25, 1976. The hydrograph result from this event can be seen in Figure 18.3. The results show that there has been an increase in volume of runoff to outlet 9501 for the scenario where no regeneration has occurred. The differences in flows range from $2.5 \%$ to $321 \%$. It is important to note that the major increase occurs during the first part (initial $2 \mathrm{~h}$ ) of the event. It is during the first parts of a rainfall event, when the soil surface in not saturated, that the infiltration properties have more influence on the shape of the hydrograph. The results show that the infiltration properties of the permeable pavement in the subcatchment that flows to outlet 9501 have been reduced.

Finally, a storm event that would occur approximately $10 \mathrm{y}$ after the beginning of the installation was examined. The resulting hydrograph from this event can be seen in Figure 18.4. The figure shows there has been an increase in volume of runoff to outlet 9501 . The differences in flows range from $17 \%$ to $600 \%$. This result appears to be reasonable and our modified version of SWMM appears to be able to model the long-term degradation of the infiltration properties under these conditions. To examine the validity of the degradation function and to see whether or not the model fits observed data, requires further work. Longterm data is currently not available for permeable pavement installations.

\subsubsection{Test 1 Results}

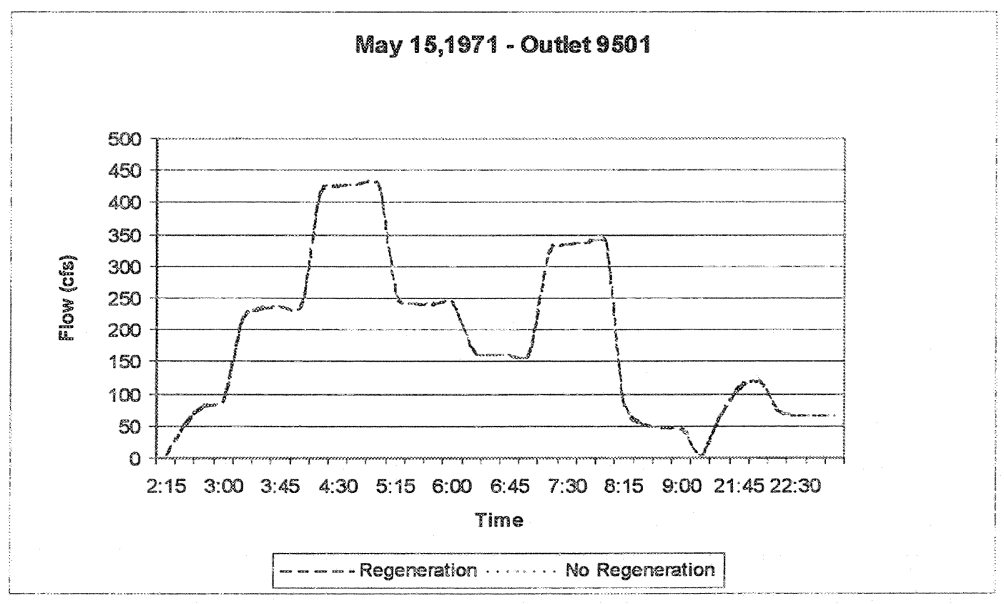

Figure 18.2 Hydrograph for May 15, 1971. 


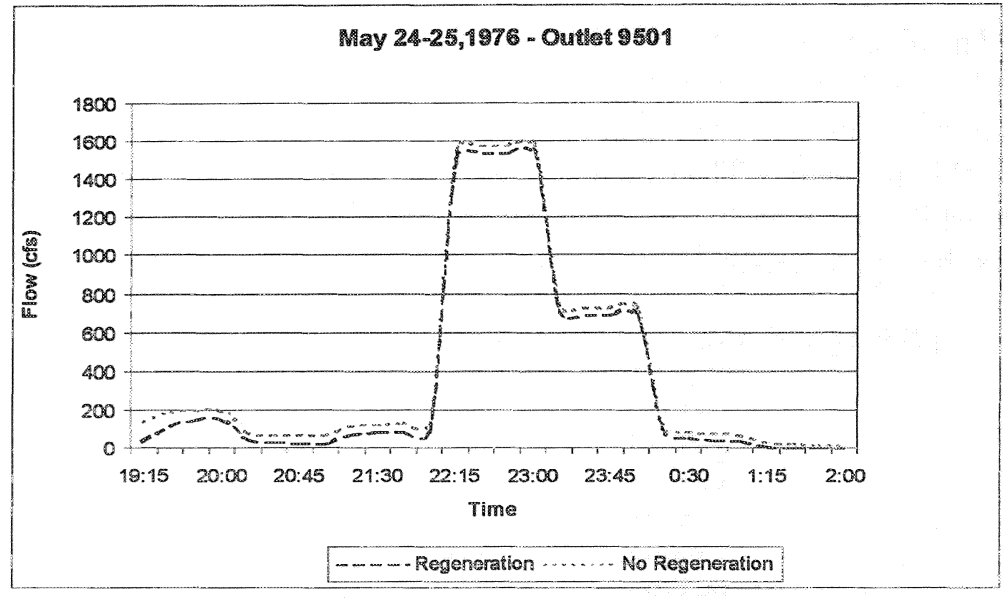

Figure 18.3 Hydrograph for May 24-25, 1976.

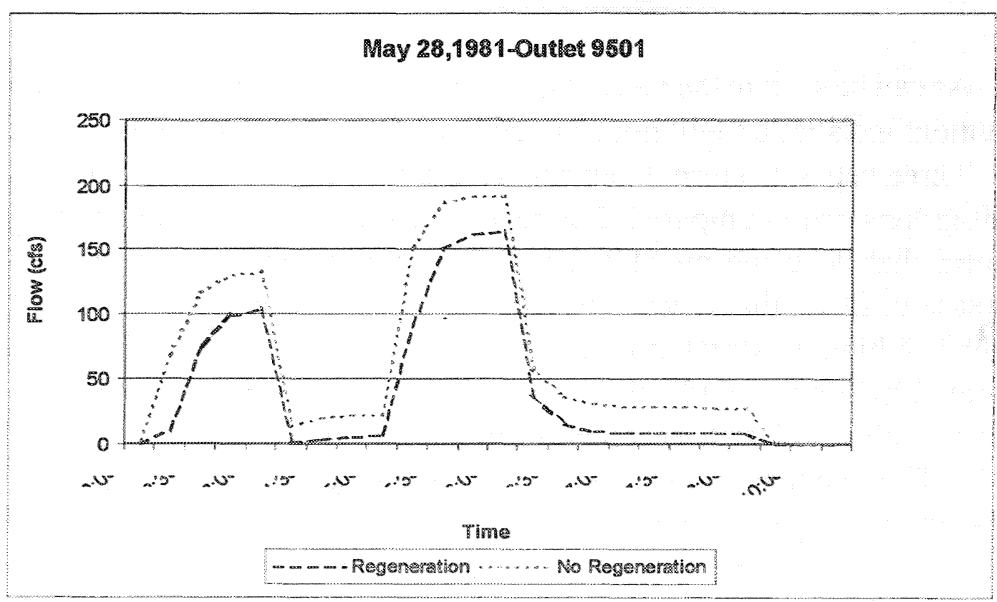

Figure 18.4 Hydrograph for May 28, 1981.

\subsubsection{Test 2- Comparison of Impervious versus Degradable Permeable Pavement}

The second test examined how the new version of SWMM RUNOFF modeled the degradation of the infiltration properties over time. Each subcatchment had similar properties. Test run $2 \mathrm{a}$ consisted of subcatchments that were $100 \%$ impervious. Test run $2 b$ had no standard pervious surface simulated; half of the subcatchment surface was permeable pavement while the other half was impervious. 
The objectives of this test were two fold; first, as previously mentioned, to test whether the model simulates degradation of the infiltration properties over time, and second, to evaluate elimination of impervious area and replacement with permeable pavement. This situation could be compared to the replacement of a large asphalt parking lot with a permeable pavement installation. Table 18.5 shows the characteristics of the permeable pavement used in this simulation.

Table 18.5 Description of permeable pavement parameters for Test $2 \mathrm{~b}$.

\begin{tabular}{cc}
\hline Variable & Value \\
\hline PERAREA & $50.0 \%$ \\
PWSTORE & $0.17 \mathrm{in}(4.3 \mathrm{~mm})$ \\
PRESIS & 0.024 \\
PSUCT & $4.00 \mathrm{in}(102 \mathrm{~mm})$ \\
PHYDCON & $0.5 \mathrm{in} / \mathrm{h}(12.7 \mathrm{~mm} / \mathrm{h})$ \\
PSMDMAX & 0.34 \\
DEGRAD & 0.002 \\
PREGEN & 6000 \\
\hline
\end{tabular}

As can be seen in the above table the infiltration properties of the permeable pavement installation will not be regenerated during the simulation.

Three separate storm events were examined for the two scenarios and the hydrographs were compared. Figure 18.5 depicts the computed hydrograph for a storm that occurred on May 10,1971. Results indicate that there is a large decrease in flows that enter outlet 9501 . The reduction of flows would be even larger if a higher saturated hydraulic conductivity was used. The value of the saturated hydraulic conductivity was $12.7 \mathrm{~mm} / \mathrm{h}^{-1}$ [ $\left.0.5 \mathrm{in} / \mathrm{h}\right]$, which is comparable to sandy soil with excellent infiltration properties (Huber and Dickinson, 1988). This comparison shows how the reduction in impervious area and the replacement by permeable pavement can greatly reduce flows. The reductions in flow rates ranges from $30 \%$ to $300 \%$ and, again, much of the difference occurs during the first part of the storm event.

The next storm event examined occurred approximately 5 y later on May 6-7, 1976. Figure 18.6 shows the two hydrographs that were computed for both scenarios. Figure 18.6 clearly shows the effect of the degradation of the infiltration properties of the permeable pavement installation on the outflows at outlet 9501 . The two hydrographs are virtually identical. The differences in the flow rates range only from $0.1 \%$ to $5 \%$. This shows that the permeable pavement's infiltration properties have degraded, after $5 \mathrm{y}$, to the point that they are essentially impervious. The need for regular maintenance of these types of installations is very apparent.

To reconfirm the notion that the permeable pavement was virtually impervious, another storm event approximately $10.5 \mathrm{y}$ from the beginning of the simulation was examined. Figure 18.7 shows the computed hydrographs from 
a storm event that occurred on October 26, 1981. As in the previous figure, the hydrographs are almost identical, except that at particular points on the hydrograph the permeable pavement scenario gives higher flows than the impervious pavement.

\subsubsection{Test 2 Results}

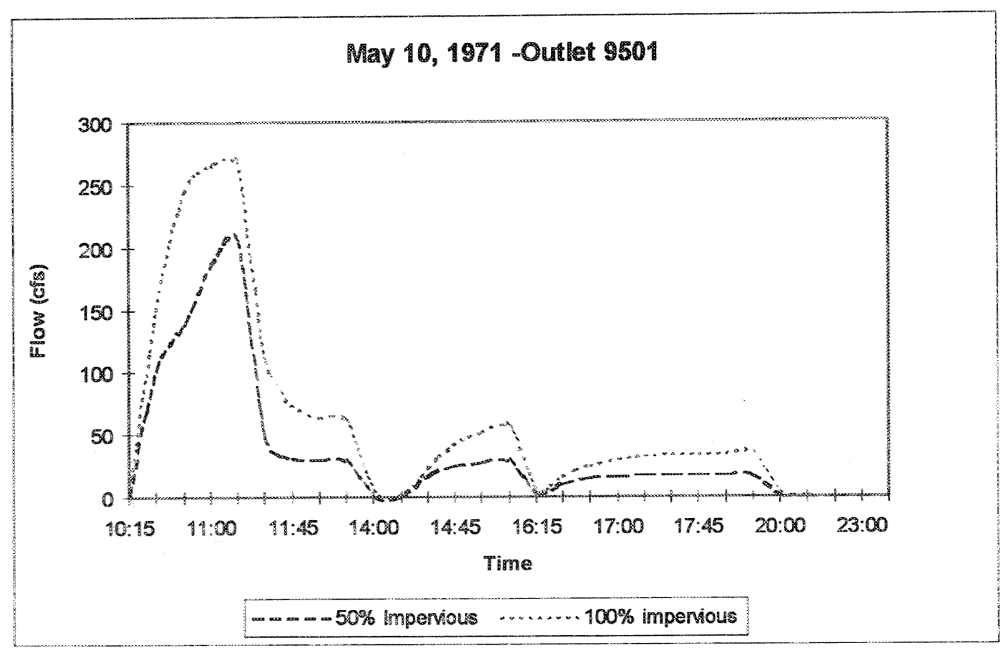

Figure 18.5 Hydrograph for May 10, 1971.

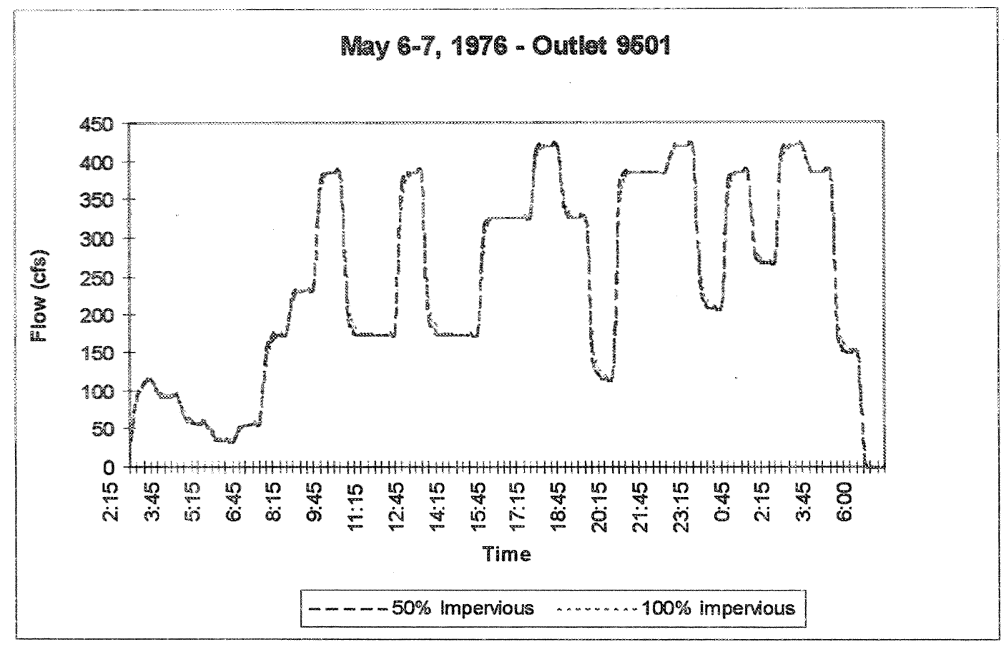

Figure 18.6 Hydrograph for May 6-7, 1976. 


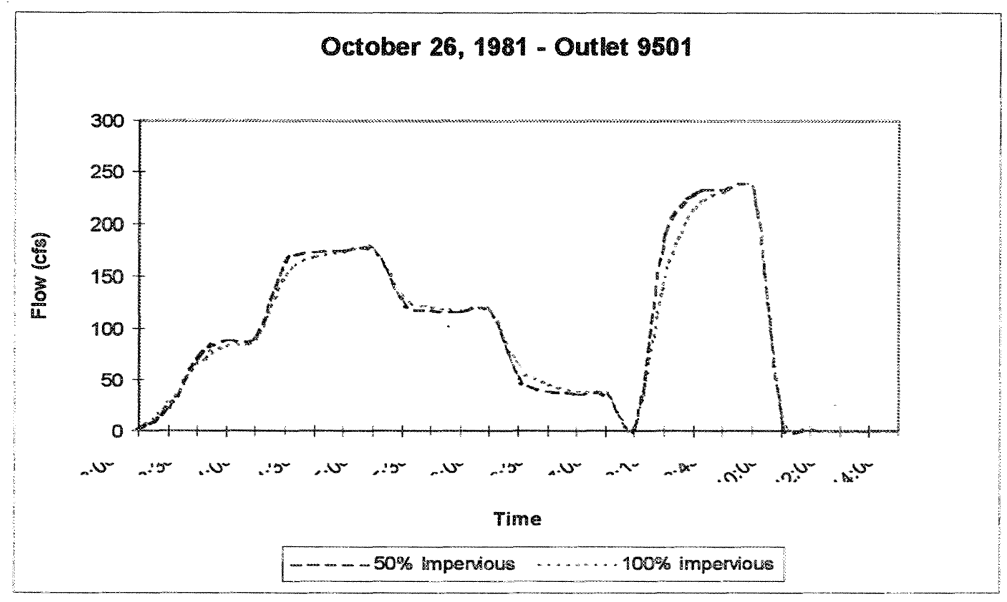

Figure 18.7 Hydrograph for October 26, 1981.

However, the $100 \%$ impervious surface also gives higher flows at certain points on the hydrograph. These differences may be attributed to the differences in the Manning coefficient for the two surface types. Examination of the total volume of runoff that flows off of the subcatchment for both scenarios reveals that there is very little difference $(2.75 \%)$.

\subsubsection{Test 3 - Comparison of Different Saturated Hydraulic Conductivities}

The configuration of the catchment for Test 3 was similar to the catchment used in Test 2. Half of each subcatchment was impervious and the other half was permeable pavement surface type. Table 18.6 shows the parameters used for the permeable pavement installation.

Table 18.6 Description of permeable pavement parameters for Test 3 .

\begin{tabular}{cc}
\hline Variable & Value \\
\hline PERAREA & $50.0 \%$ \\
PWSTORE & 0.17 in $(4.3 \mathrm{~mm})$ \\
PRESIS & 0.024 \\
PSUCT & $4.00 \mathrm{in}(102 \mathrm{~mm})$ \\
& 1.5 to $0.5 \mathrm{in} / \mathrm{h}$ \\
PHYDCON & $(38.1$ to $12.7 \mathrm{~mm} / \mathrm{h})$ \\
PSMDMAX & 0.34 \\
DEGRAD & 0.002 \\
PREGEN & 6000 \\
\hline
\end{tabular}


From the table it can be seen that the only parameter that is different between the two scenarios is the saturated hydraulic conductivity. The objective was to determine the potential benefit of using soil materials that have high infiltration capacities in the permeable pavement structure. Figure 18.8 shows the computed hydrograph for a storm that occurred on May 10, 1971. Results are as to be expected. An increase in the saturated hydraulic conductivity of the permeable pavement greatly reduced the volume of runoff from the subcatchment that flows to outlet 9501 during this first $2 \mathrm{~h}$ of the storm event. The hydrographs are virtually the same after the initial 2-h period, after the surface soil, in both scenarios, had reached saturation.

From the previous tests, it is obvious that after approximately five years the permeable pavement behaves essentially as an impervious surface. Therefore, when comparing the benefits of using soils with improved infiltration capacities it was necessary to examine a storm event that occurred approximately two years after the beginning of the simulation. Figure 18.9 shows the comparison between these hydrographs for an event on June 23, 1973. This figure shows that the permeable pavement, with a saturated hydraulic conductivity of $1.5 \mathrm{in} / \mathrm{h}(38.1$ $\mathrm{mm} / \mathrm{h}^{-1}$ ), still provides reduced flows to outlet 9501 . However, the difference in flows between the two scenarios has decreased.

Figure 18.10 shows that after a longer period of time both scenarios respond to a rainfall event in a similar manner. The hydrographs depicted in the figure are from a storm event that occurred on May 31,1976. The hydrographs are very similar, although the $38.1 \mathrm{~mm} / \mathrm{h}^{-1}\left(1.5 \mathrm{in} / \mathrm{h}^{-1}\right)$ scenario does show smaller volumes of runoff near the beginning of the storm event.

\subsubsection{Test 3 Results}

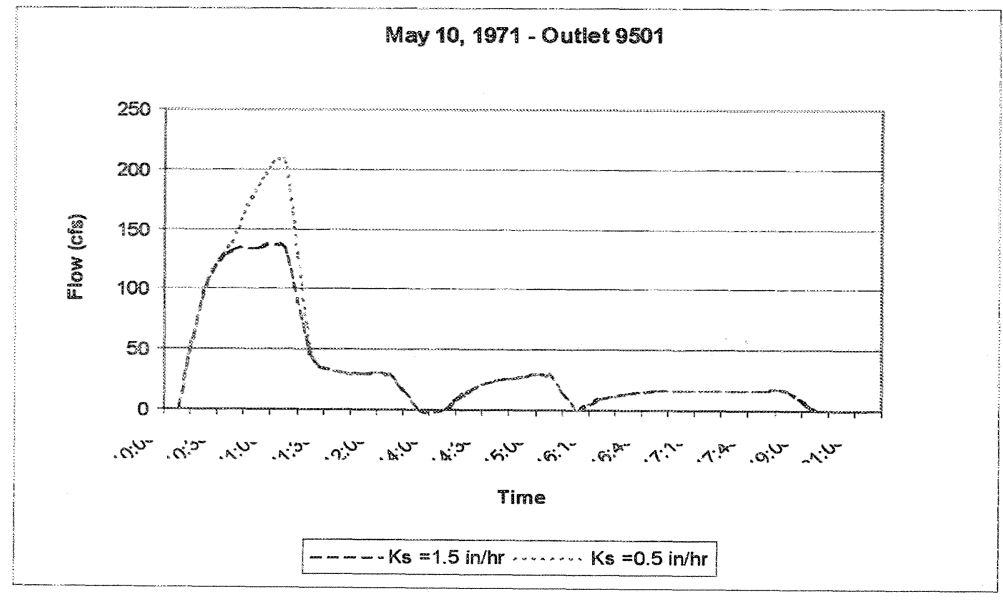

Figure 18.8 Hydrograph for May 10, 1971. 


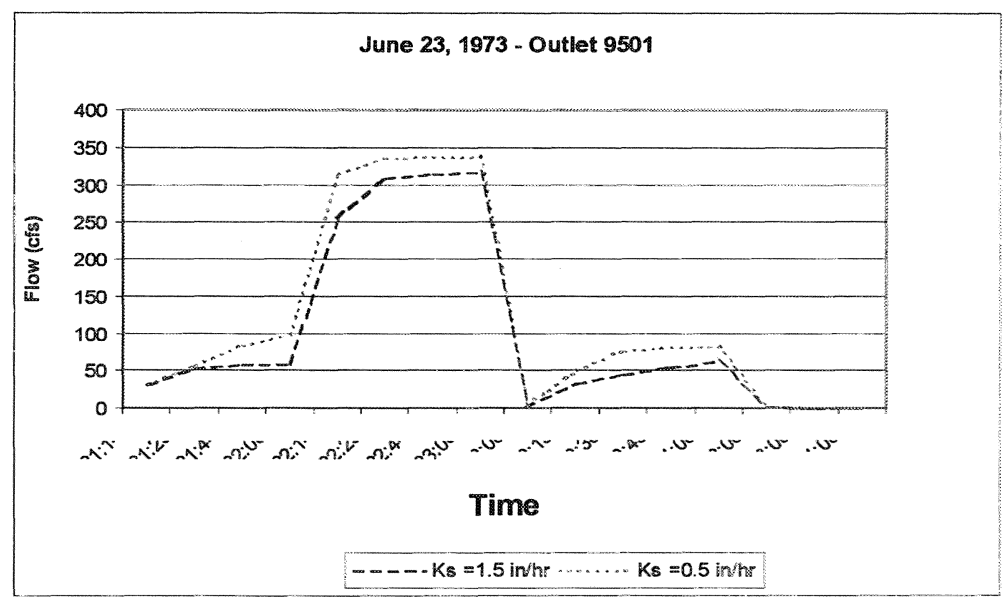

Figure 18.9 Hydrograph for June 23, 1973.

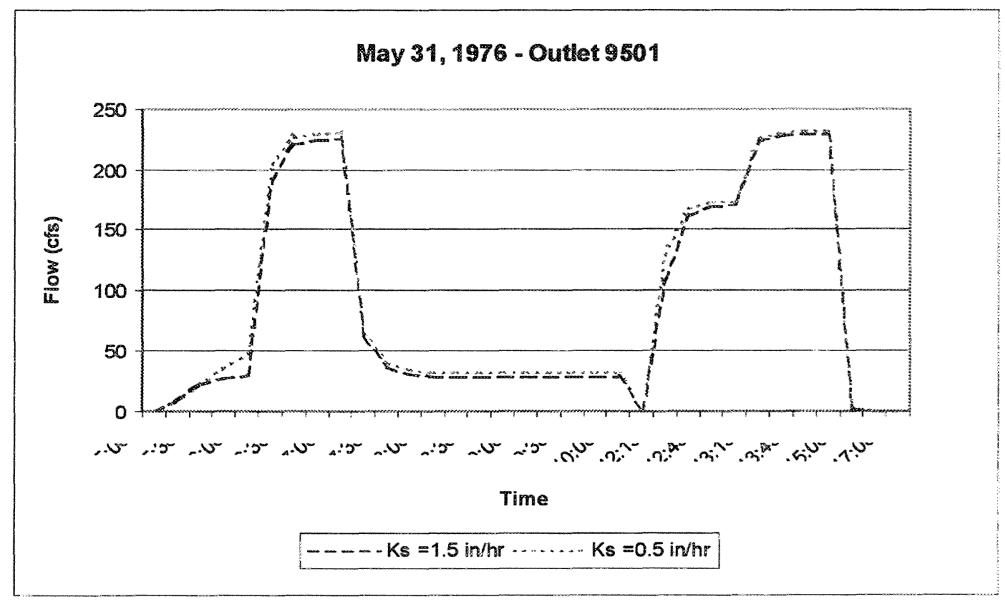

Figure 18.10 Hydrograph for May 31, 1976.

\subsection{Conclusions and Recommendations}

Our study shows that it is possible to insert new FORTRAN source code into the model that accounts for the degradation of the infiltration capacity. The new code uses an exponential decay function in conjunction with the saturated hydraulic conductivity to change the infiltration capacity over time. The new code also allows for the possible regeneration of this property through proper maintenance of permeable pavement installation. Several long-term simulations were conducted 
to examine whether the proposed new source code produces reasonable results. No observed data from real permeable pavement installations were available, therefore the examination of the hydrographs produced by the simulations was qualitative. However, the results describe the expected degradation of the infiltration capacity of permeable pavement over time. It appears to be a good design approach, in that the well-known Green-Ampt parameters can now be calibrated for specific applications.

We further recommend that:

1. The validity of the new source code must be tested using observed data from permeable pavement installations.

2. Modifications should be made if necessary to ensure that the permeable pavement subroutine is properly connected to the groundwater routine.

3. Clarification of the water depth in the reservoir of the permeable pavement structure should be made.

4. Further research must be done on the degradation of the infiltration capacity (see Chapter 1 in this monograph).

5. Appropriate guidelines for maintenance frequency must be established to ensure that the flow reducing qualities of permeable pavement remain effective.

6. Modifications to the SWMM code should be made to incorporate the water quality aspects of permeable pavement for long-term continuous simulations.

7. Proper documentation must be prepared to support the proposed new code.

8. Instructional material should be developed and distributed on the use of the proposed new code.

\section{Acronyms and Notation}

$\mathrm{A}_{\mathrm{pp}}$
$\mathrm{A}_{\mathrm{s}}$
DEGRAD
EDC
$\mathrm{fE}_{\mathrm{o}}$
$\mathrm{H} 6$
imp
$\mathbb{K}$
$\mathrm{K}_{\mathrm{s}}$
$\mathrm{L}$

permeable pavement area, $\mathrm{m}^{2}$

subcatchment are, $\mathrm{m}^{2}$

degradation coefficient, time ${ }^{-1}$.

external drainage cell

overall average effective infiltration capacity.

group identifier in SWMM

imperviousness, $\%$.

decay coefficient, time ${ }^{-1}$.

saturated hydraulic conductivity, $\mathrm{mm} \times \mathrm{hr}^{-1}$.

depth of upper most soil layer, $\mathrm{mm}$ [in.]

MICBEC Modular interlocking concrete block- internal drainage cell type. 
OM organic matter.

PERAREA percentage of the perious area for the specific subcatchment that is permeable pavement $(\%)$.

PERMEA.INC used to pass variables associated with the new permeable pavement option.

PERMPAV.FOR based on the Green-Amp method, this is used to calculate the hydrological response of permeable pavemtent.

perv pervious area that is permeable pavement, $\%$.

PHYDCON Saturated hydraulic conductivity of soil, $\mathrm{mm} \times \mathrm{hr}^{-1}\left[\mathrm{in} . \times \mathrm{hr}^{-1}\right]$ for the upper most layer of the permeable pavement installation.

PREGEN Average length of time between mechanical regeneration of permeable pavement infiltration properties, days.

PRESIS Permeable pavement area Manning's roughness.

PSMDMAX Initial moisture deficit for soil, volume air/volume voids (fraction) upper most layer of the permeable pavement installation.

PSUCT Average capillary suction, $\mathrm{mm}$ [in.] of water for the upper layer of the permeable pavement installation.

PWSTORE depression storage for permeable pavement, $\mathrm{mm}$ [in.].

$\mathrm{t}$ time since generation has occurred, or time from permeable pavement installation.

WSHED.FOR source code for computing the instantaneous water depths and flow rates for the subcatchment areas, called with the HYDRO.FOR subroutine.

\section{References}

Borgwardt, S. 1994. Test on UNI Eco-Stone installations of different ages: report for Uni-International. Institute for Planning Green Spaces and for Landscape Architecture, University of Hanover.

Ferguson, B. K. 1994. Stormwater infiltration. Lewis Publishers, CRC Press Inc. Boca Raton, Florida. 269 pp. ISBN: 0873719875.

Huber, W.C. and Dickinson, R.E. 1988. Stormwater management model, user's manual, version 4. US Environmental Protection Agency, Athens, Georgia. 569 pp.

James, W. 1994. Rules for responsible modelling. CHI, Guelph, Ontario. 144p.

James, W. and Shivalingaiah, B. 1985. Stormwater pollution modelling: Build up of dust and dirt on surfaces subject to runoff, Canadian J. of Civil Engineering. 12(4): 906-915.

James, W. and B. Verspagen. 1996. "Thermal Enrichment of Stormwater by Urban

Pavement." Journal of Water Management Modeling R195-08. doi: 10.14796/JWMM.R195-08.

Kipkie, C. W. 1999. Feasibility of a permeable pavement option in the Storm Water Management Model (SWMM) for long.term continuous modelling. M.Sc. thesis, School of Engineering, University of Guelph, Guelph, Ontario, Canada. 
Kresin, C., W. James and D. Elrick. 1996. "Observations of Infiltration Through Clogged Porous Concrete Block Pavers." Journal of Water Management Modeling R195-10. doi: 10.14796/JWMM.R195-10.

Maryland Department of Natural Resources. (MDNR) 1984. Water Resources Administration, Stormwater Management Division. Maryland Standards for Stormwater Management Infiltration Practices. Tawes State Office Bldg., Annapolis MD 21401. Mikkelsen, P.S., Weyer, G., Berry, C., Walden, Y., Colandini, V., Poulsen, S., Grotehusmann, D. and Rohlfing, R. 1993. Pollution from urban stormwater infiltration. Proc. of the Sixth Int'l Conf. on Urban Storm Drainage, Vol. 2, Maralek, J. and Torno, H.C. eds. Seapoint Publishing, Victoria, British Columbia. pp. 11871194. ISBN:1-55056-253-3.

Muth, W. 1988. Drainage with interlocking pavers. Research Inst. for Water Resources: Karlsruhe University of Engineering. No. 8711-UNI. Abridged and Translated Version. 4 pp.

Nawang, W.M. and Saad, S. 1993. Stormwater infiltration investigation using porous pavement. Proc. of the Sixth Int'l Conference on Urban Storm Drainage, Vol. 2, Edited J. Maralek and H.C. Torno. Seapoint Publishing, Victoria, British Columbia. pp. 1092-1097. ISBN: 1-55056-253-3.

Nix, S.J. 1994. Urban stormwater modelling and simulation. Lewis Publishers, CRC Press. Boca Raton, Florida.

Phalen, T. 1992. Development of design criteria for flood control and ground water recharge utilizing UNI Eco-Stone and Ecoloc Paving Units. Northeastern University, Boston, Massachusetts.

Pratt, C.J., Mantle, J.D.G and Schofield, P.A. 1989. Urban stormwater reduction and quality improvement through the use of permeable pavements. Water Science and Technology. 21:769-778.

Pratt, C.J., Mantle, J.D.G. and Schofield, P.A.. 1995. UK research into the performance of permeable pavement, reservoir structures in controlling stormwater discharge quantity and quality. Water Science and Tech. 32:63-69.

Rollings, R.S. and Rollings, M.P. 1992. Applications for concrete paving block in the United States market. A Rep. for UNI-Group U.S.A.

Schueler, T.R. 1987. Controlling urban runoff: A practical manual for planning and designing urban BMPs. Prepared for the Washington Metropolitan Water Resources Planning Board. Publ. No. 87703. Washington, D.C.: Metropolitan Washington Council of Governments. 1.1-9.19 pp.

Shackel, B. 1995. Infiltration and the structural test of UNI Eco-Loc and UNI Eco-Stone Paving. School of Civil Engineering, University of New South Wales, Australia.

Urbonas, B.R. and Stahre, P. 1994. Stormwater: Best management practices and detention for water quality, drainage and CSO management. Prentice-Hall, N.J.

Weatherbe, D.G. 1995. "A Simplified Stream Temperature Model for Evaluating Urban Drainage Inputs." Journal of Water Management Modeling R183-16. doi: 10.14796/JWMM.R183-16.

Xie, D.M. and W. James. 1994. "Modelling Solar Thermal Enrichment of Urban Stormwater." Journal of Water Management Modeling R176-13. doi: 10.14796/JWMM.R176-13. 


\section{.}

